\title{
FIFTY YEARS OF SURGERY IN THE ROYAL ARMY MEDICAL GORPS
}

BY.

\author{
Brigadier D. FETTES, O.B.E., M.B., F.R.C.S., K.H.S.
}

A HALF-CENTURY ominously ushered in by a war, albeit one run on sporting lines, the last of the humane wars; then a short decade, free only in its early years from the gathering war clouds, only remembered as their training years by the oldest now serving; and all the rest a crescendo of wars; no wonder that it is the record of half a century of progress in war surgery. For the regular Army surgeon it has been a career devoted to war, with lesser wars between greater wars, against Mahsuds, Moplahs and Marris, Afghans and Afridis; little else than wars and preparations for war; and for the civilian surgeons, years in uniform, for many a one, a third of his professional life.

It has been a half-century of surgical striving, step by step in every climate, in the cold wet infected mud of Europe, in sweltering deserts and jungles, mountains, plains and veldts, in invasions and evacuations, in headlong retreat, in static warfare, in precipitous advance; from battlefield to hospital sometimes a matter of an hour or two, over good roads or perhaps a trek of three weeks over a roadless waste-in practically every conceivable condition and climate. Each campaign has taught something new, but every apparent surgical advance has had to be tested under all these circumstances, for, without these controls, no innovation in war surgery can be accepted as an advance. Few of these world-wide opportunities came the way of any other nation, it was Britain's task and a task very much after Britain's heart.

It is also the tale of the evolution of weapons and missiles. Had there been an embargo on the development of weapons of destruction, we might be less able to alleviate suffering, but there would not now be a world of preventable suffering to alleviate. On the other hand, surgery, military and civil, would not have advarnced at the speed it has.

In the South African War the missile was the high-velocity bullet. A good deal of concern was expressed about the pôssibility of blunt-nosed and expanding bullets being used-missiles which were not quite cricket; happily it could not then be foreseen what the future held in store. Explosive shells were used, the proportion of bullet to shell wounds being about nine to one, but their effects were not greatly feared; shrapnel shells were often made to burst very high and cause little damage, in fact the eye witnesses of the day referred to the attendant noises as the most unpleasant feature of rapid shellfire; happily again they could not foresee what their sons and grandsons would be called on to endure. The campaign was a little unfortunate from the surgical point of view, the bullet was about half the size it had been in former wars, it did not tend to carry in clothing, and inflicted small wounds and tracks which rarely caused serious trouble wherever placed; there were plagues of flies but the 
veldt was about as sterile as a desert. Had subsequent wars been fought under the same conditions, the surgery of the South African War would have formed a valuable precedent, as it was it merely gave a false sense of security.

The surgery of that campaign is largely forgotten, that of later wars is not: it is of value therefore to recount briefly the methods practised at the opening of this century. They may give a better impression of how time has marched on since then.

On the battlefield a first field dressing and sometimes an antiseptic paste were applied to the wounds. At the Field hospital there was thorough cleansing of the surrounding skin and wound, which was dressed with double cyanide gauze.

Compound fractures were treated conservatively when the wounds were small but were explored early and bone fragments removed when the exit wound was large, the wound being left open without drains or plugs unless there was frank infection. Internal fixation by screw or wire for oblique fractures was considered justifiable. Immobilization was effected by plaster of Paris, wire and wooden splints; a cane folding splint was popular for thigh and leg fractures during transportation, but Hodgen's splint was in use in hospitals. Fractures of the femur were regarded as the most formidable of limb wounds, 15-20 per cent required amputation at the base and the overall mortality was around 15 per cent. Most serious fractures were held for three to four weeks before transfer to the Base, the rule being that no fractures of the leg and thigh, and few of the arm, could be transported for any distance without serious trouble developing.

Joint wounds were not a problem; on simple expectant treatment suppuration was rare and functional results were excellent.

Deaths from external hæmorrhage were unusual but, as one would expect, traumatic aneurysms were common and progress was made in the study of vascular injuries in war. Cases severely shocked were treated in the supine position with strychnine and pre-operative saline infusion. The merits of chloroform as an anæsthetic were extolled: Removal of foreign bodies was performed at Base hospitals; in localization, X-rays had replaced the probe.

Operations were avoided if possible in the Field hospitals; except amputations and for head wounds. When operations were considered necessary the importance of their being performed early was well recognized, and a very high priority was given to head injuries - all skull splinters, and all pulped brain which would wash away were removed, the scalp was closed without drainage, primary union being regarded as of first importance.

Penetrating bullet, shell, and shrapnel wounds of the chest all did remarkably well. Hæmothoraces were tapped to relieve pressure, but the usual course of all was to spontaneous recovery and empyema was regarded ás a sequel to tapping or opening. Adhesions were the rule and it was customary to invalid all chest wounds because they suffered breathlessness on exertion: and pain. There had been great expectations of advances in the treatment of abdominal wounds : as it turned out there was only disappointment. Small calibre bullet wounds of solid viscera presented no problem and it was known that a certain 
proportion of intestinal wounds recovered spontaneously. Apart from that at the end of the campaign it had to be confessed that operative surgery had scored but few successes. An eminent consultant recorded that he had met no case of recovery following visceral injury due to a large bullet. This failure was attributed to the severity of the local injury and to the fact that cases came to operation too late. Serious lesions of the small intestine appear to have been even more feared than those involving the large bowel, which were considered to have a greater tendency to become sealed off by adhesions and form a circumscribed abscess amenable to surgery, the whole process being doubtless life-saving as a colostomy. There were successes but operative treatment was so disappointing that the policy became one of hoping for spontaneous recovery, watching rather than operating, excluding from operation all cases likely to die early, and expecting a fatal result from operation. Yet the opinion expressed at the close of the campaign was that severe injuries should have operative treatment, and that it would be from this class of case that the real successes of the future would be drawn. Makins describing his experiences with the wound involving the posterior aspect of the colon, concludes: "In the future I should always feel inclined to enlarge such wounds and bring the bowel to the surface"-a prophetic remark which if acted upon might have altered surgical history earlier, and might have compensated for the other disappointments.

That briefly is the story of the surgery of the South African War; it was a campaign of slow evacuation, with stretcher bearers easier to obtain and feed than transport animals, it was the day of the covered wagon, yet surgeons dreamed dreams of the days of mechanization, foreseeing a great future for the traction engine. "Traction engines were so far as known, never employed as a means of transporting the sick, the tendency of these machines to stick in the mud and break down bridges is well known but putting these disadvantages aside, with a supply of fuel ensured, and such roads as are afforded by a civilized country, a great future is probably before this means of transport for the wounded. A large number of patients might be carried at an even pace, and the camps saved all the trouble and worry of the transport animals."

There followed a decade of peace: The Surgeon General at the College attempted to compile the surgical history of the war and his comments are illuminating. "He complained that from stress of work, surgeons had little time to indulge in note taking, that of the 23,000 wounded officers and men who passed through the hospitals, case notes of only 1,650 were of any surgical interest. He complained of looseness in diagnosis - "gunshot wounds," giving no site, "gunshot wound of leg," giving no indication of fracture-and considered that the solution was a card system for each patient from the time of wounding and the establishment of a statistical bureau at the base; all good advice for the future. History goes on repeating itself.

Following the war, the civilian surgeon stored his uniform, and the regular Army surgeon returned to his peaceful pursuits, caring for the soldier and his family wherever they might be, not always in unpleasant places, Canada and South Africa were still on the foreign service list, while service in unhealthy lands still counted double. The Professor at the College taught military sur- 
gery of 1901 pattern. If he had concentrated on a two-word slogan "early treatment," he would perhaps have epitomized the lessons of the previous war. New editions of the books published after the South African war appeared in 1913 and were regarded as the last word on the subject of military surgery. The very last year of real peace drew to a close, and the present writer emerged one fine evening in 1914 into St. Martin's Lane from seeing Gaby Deslys in Rosy Rapture, to find on the newspaper placards in screaming headlines "England Mobilizes." Shortly afterwards he was receiving the first cases from the battlefields at a home hospital, and a little later had charge of tetanus cases in a military hospital: - From Rosy Rapture to "tetanus" describes the transition from war to peace in 1914 and the realization that the clean perforation of a rifle bullet in a pastoral country, was one thing, and the mutilations by new missiles in the heavily cultivated fields of Flanders were something shatteringly new.

In the early days medical units were swamped by the deluge of wounded, over 54,000 in 1914; 206,000 in 1915 (38,000 from the battle of Loos alone); while the cost in casualties of the first two days of the battle of the Somme was 58,000 . The total number wounded in France and Flanders alone was 1,988,969, a frightful problem, especially in the early days of first impact.

The weapons of this war were the machine gun, capable of concentrated fire at the rate of 400-500 shots a minute instead of the rifle's 20 odd, inflicting more severe injuries than any previously seen in war; high explosive shells causing 73 per cent of casualties under static warfare conditions, with greater danger of infection, and twice the fatality of bullet wounds. Mortars, grenades, aircraft bombs and land mines completed the list.

Worse than the numbers were the infections and the frequency of anaerobic contaminations. Gas gangrene had been comparatively rare before the war and very rare in any previous campaign. In No. 1 C.C.S. in 1915 the incidence was assessed at 5 per cent of the wounded, while the incidence of tetanus in the Army in France in September 1914 was 8.8 per 1,000 . Bullets carried in infection from filthy mud-soaked garments as never before, and shell fragments carried in pieces of the garments themselves.

In the Mons retreat in 1914 there was no possibility of early surgery and even when the line became stabilized, the problem was such a vast one for a Medical Service unprepared for such eventualities, that there could be little organized early surgery until the spring of 1915, while in battle periods throughout the war, the influx of wounded was so great that early treatment was generally a counsel of perfection, and something under twenty-four hours' time lag before operation was as good as could be hoped for. The Regular Army had been decimated in the retreat, what remained and took its place spent the next three years underground. Enveloped in a sea of mud each winter, suffering from frost-bite and trench-foot-about 20,000 cases a year-trench fever and all the other ills, not to mention horrors associated with trenches and dugouts, chlorine, phosgene and mustard gases added to the weapons of destruction they had to fight against, their expectation of life during battles a matter of minutes, and maiming their only hope of release, what degree of resistance 
to severe infection could these men have had? They were to talk in a later war of the men in a famous Army as "every man an emperor," it would be fair to talk of these 1914-18 men as "every man a man, whose like we shall not see again."

A few landmarks in the 1914-18 War are all that space permits. Surgeons had expected cases to behave benignly and were quite inexperienced in the treatment of infections more severe than any seen since the days of Lister. Surgical facilities in the forward area were quite inadequate. All operations had to be done at the Field Ambulances and they were unable to cope with the situation. Not until the end of 1915 did the role of the Field Ambulance become limited to securing rapid evacuation, preventing shock, and performing those life-saving operations which are still that unit's responsibility to-day. First-aid treatment, far more often than not, was all that was possible; the application of antiseptics at the time of wounding was soon omitted as it did nothing to prevent infection and initial treatment was limited to applying the first field dressing.

Fractures at the start were inmobilized in wooden splints, the internal angular and Gooch's for the arm, the back splint with foot and side pieces for the leg, and the long Liston for the thigh. Those who remember the Liston splint will understand the mortality rate of nearly 50 per cent in fractures of the femur, the journey shocked these cases to death. By the end of 1915 the Thomas knee splint was in use in Base hospitals and in another year was in general use in forward areas. Its introduction halved the mortality in fractures of the femur. It was and is the most valuable first-aid invention in war surgery. The wounded soldier with his femur smashed owes a very great deal and often his life to Hugh Owen Thomas.

Motor ambulance cars had been rushed out for the battle of the Aisne in September 1914, motor ambulance convoys were becoming more organized, and with the appearance of a new unit, the Casualty Clearing Station, real steps were taken to bring surgery to the wounded and cut down the period of dangerous delay. From small beginnings these units increased in size, equipment, and personnel, so that by the time of the Battle of the Somme, the Fourth Army had fourteen of them, and also an advanced operating centre. Some of these C.C.S.s had 1,000 beds and on the first night of the battle were housing 1,300 patients. They were intended to be mobile units but had a tendency to develop such elaborations in equipment, as almost to immobilize them.

Until then the days had been grim indeed. Surgeons, mistakenly perhaps, had concentrated on antiseptic attack on the infections. Mercurials, pure carbolic, lysol, formaline, salt packs, BIPP, eusol-all were tried and sometimes showed some promise; the Carrel-Dakin method did have success, for in addition it did achieve very thorough drainage. For many months wounds closed or inadequately drained reached the Base in a terrible state, while those adequately opened up arrived infected but in reasonably good condition. It took time to elaborate the principles of excision of all contused and lacerated tissues and the removal of all fragments of clothing and foreign bodies but it was this 
policy that dealt a real blow to infection and was the most potent factor in the prevention or arrest of gas gangrene.

The suture of wounds, catastrophic in the early days, happily fell into disuse for a year or two, but with the development of adequate preliminary surgery was safely revived and, by the end of the war, cases untreated for as long as forty-eight hours were being closed by primary or delayed primary suture. Some series showed 88 per cent successful closure even when surgery. had been delayed for forty-eight hours, others 95 per cent successful when operation was within twenty-four hours.

For the first time in war, orthopædic centres were established with far greater continuity in treatment, physiotherapy and rehabilitation. Limbs previously doomed were saved, while men who formerly would have been completely incapacitated with stiff and useless limbs returned to fight or to do useful work in industry.

By 1917 shock was being tackled systematically on the same general lines as at present. When an infusion was considered advisable gum was preferred but blood transfusion was being practised by various methods, the citrate method being accepted inally as superior. In that year transfusion officers were giving blood in selected aid posts. The art was in its veriest infancy, of value at times of no great activity, but not organized for mobile warfare with heavy casualties.

Chloroform was the only anæsthetic made available at the start. Warm ether vapour, and gas and oxygen replaced it with happy results. Anæsthetic specialists appeared for the first time in 1916; two hundred nursing sisters gave anæsthetics skilfully in 1918, freeing doctors for front-line work.

As in other situations, wounds of the chest followed a sadly different course from that of previous campaigns or contemporary campaigns like that of Palestine, the more modern missiles causing greater damage, and the soil greater risk of infection, anaerobic and streptococcal. In 1914-15 the mortality rate in cases reaching medical units was nearly 30 per cent and, when infection occurred, 50 per cent died. At the start the fear of pleural reflexes and of re-starting hæmorrhage deterred surgeons from attempting any really cleansing operations. Infection was dealt with by simple rib resection and drainage-life saving in some, but with crippling after-effects in a proportion of those recovering. It did not take long to discover that aspiration of a large hæmothorax on the first or second day did not have untoward effects and this discovery had some result but it soon was realized that wounds of the chest must be dealt with as were wounds elsewhere. By 1917 thoracotomies were being performed on 38 per cent. of all chest wounds, the parietes, pleural cavity and lung being dealt with, but the results to the end of hostilities were somewhat disappointing.

Especially in the case of abdominal wounds did the shadow of South Africa obscure the paths of progress. For a year, in all the Armies, expectant treatment was the rule. Care was lavished on the wounded abdominal case but the patient nevertheless died slowly, without benefit of surgeon. It became evident that hæmorrhage was so commonly" a cause of death, and the visceral 
injuries were so extensive, that nothing short of operation could be of any avail. Operative therefore replaced expectant treatment and by the time of the Battle of Loos in September 1915, abdominals were given the highest priority in evacuation to C.C.S.s and advanced operating centres. Before this policy was adopted over 80 per cent of abdominal wounds died. When, however, early surgery was the policy, the overall mortality was over 50 per cent; of small intestine wounds 65.9 per cent died; of large intestine wounds $58 \cdot 7$ per cent died. These figures do not denote any additional risk from colostomy but the interesting fact emerges that in the first world war there was greater danger of death from colonic wounds subjected to colostomy ( $73: 5$ per cent), than in those sutured (just over 50 per cent), and the danger was greater in both instances than in the phase before early surgical intervention was general (38.7 per cent). Delay and infection, dangerous in other wounds, were deadly in abdominal wounds, and the problem of the infected retroperitoneal tissues, often fulminating anaerobic; was a terrible one. Operation too long delayed merely spread an infection which Nature had been striving to localize. Considering all the difficulties which in these short paragraphs have only been hinted at, the results were on the whole gratifying. At best, the most immaculate surgery was a gamble against time and death on a patient who, by later standards, was nearly always insufficiently resuscitated, too often hopelessly so.

The treatment of the wounded did not end with the close of hostilities, the aftermath of a war of chronically infected wounds was a periodic breaking down of these wounds and shedding of sequestra for years to come.

Following the war of 1914-18 many of the civilian surgeons stored their uniforms, but many chose to make their career in the Regular Army-an estimable thing for the Army which thereby gains a leavening or, perhaps, a transfusion. The professor of military surgery at the College resumed his teaching, epitomizing the lessons of the previous war in the three word slogan "early thorough surgery."

The Regular Army surgeon returned to his peaceful pursuits for the next twenty years, spending much of his time in foreign parts, for in these days a foreign tour was not a protracted cruise, but an unbroken period of five years or more, and a home tour little more than a longish visit. These peaceful pursuits were not, as is sometimes believed, a round of shooting and fishing with occasional interludes of mild work. On the contrary there was not much time to spare if a fair surgical deal was to be given to the soldier and his family and many others in a parish of some 350 miles radius. The surgeon often found himself driving that distance in tropical heas that seared the eyes, to an operating theatre with no air-conditioning where two emergency operations might be just possible, but three might be too much for him; or operating at sea on acute abdomens, off Algiers, off Sierra Leone, off Port Sudan, amputating a thigh for gas gangrene in a gale in the Bay of Biscay; or crawling on hands and knees to yet another emergency in a typhoon in China; journeying. 2,000 miles to graft a bone; operating on the wounded in a perimeter camp in the heart of the frontier of India, early in the day before the awakening of the black ceiling of flies. All surgeons must have motley memories of these 
years of peace, memories of shark bites, snake bites, camel bites, rabieș, tiger maulings; violence of every description, the usual and unusual in tropical and traumatic surgery in addition to general, gynæcological, and obstetrical surgery as at home; memories poignant, for the Army surgeon must be guide, friend and parent to the soldier in his loneliness, sick unto death, far from home; memories bizarre - the gratitude of a villager, when a Winett-Orr treatment on his pregnant cow's old compound fracture has been blessed with success; the satisfaction of earning a pair of Jodhpur breeches in payment for a resected colon.

In all the peace years, however, the surgeon is merely holding the fort; preparing for war, organizing according to the lessons learnt in the last war, against the day when the alarm will sound and the civilian surgeons return; for the surgical service of the Army is not alone the Regular Army but comprises all those who stay in, and those who come, and go, and may return.

The war of $1939-45$ is too recent history to require much comment. In many and varied campaigns, the surgical doctrines of 1918 have largely been verified and largely amplified, and there does" not appear now to be so much to learn as to apply. Very many factors-early adequate surgery; the wounded man's increased ability to stand whatever operative treatment was necessary and his greater resistance to infection later, which result from full resuscitation; the "adjuvance". of penicillin to thorough surgery; the determination of all concerned to close wounds by suture of graft within a matter of days of their infliction; the increased knowledge regarding when to hold cases, and the military situation which permitted holding and good nursing; the victorious atmosphere with its psychological advantages and lessened risk of treatment centres being bombarded by gunfire or bombing - these and many other factors in the terminal triumphant years have been conducive to wounds behaving in an orderly fashion as regards infection, anaerobic and otherwise.

No miracle, however, has occurred, there is no diminution of bacteriological virulence in Flanders fields as has occurred in the case of malaria in Macedonia. One had only to visit the German wounded in their own hospitals and see the trays, collecting pus pouring from the wounded limbs of toxæmic wrecks, to realize that when everything in a campaign is going according to plan, when surgeons are expert and all they require is proyided, the care of the wounded of that campaign is of the nature of a triumphal march. This country bought dearly its knowledge of what happens in all other military circumstances and, in all future planning, the other side of the picture must never be forgotten.

In this latest war, all the old terrors reappeared and all manner of fiendish new weapons were introduced, including new varieties of land mine, which typically tear a limb off. The weapon of the war, however, was the aeroplane, and the missile the bomb, increasing in size and virulence until the atomic variety added radiation blast injuries as a new and devilish destructive force.

In the years between the wars the question of mechanization had loomed large in all military medical discussions. It can be said that the forward units in their collection and evacuation to the surgeon, have met the surgeon's demand for speed. 'For the immobilization of limbs ' plaster of Paris and the Thomas' splint are now considered to be sufficient, the former applied so as to 
avoid all constriction has been satisfactory for severe flesh wounds and arm and leg fractures, while both have been combined in the Tobruk plaster to give immensely improved immobilization to the thigh fracture during a prolonged journey.

The history of the organization of blood transfusion is recorded elsewhere. Perhaps the most striking advance has been in resuscitation, the excellence of which has been reflected in the recovery rate of seriously wounded men whose blood loss has been severe. The fact that a wounded man has blood returned to him as fast as he bleeds, has made surgery reasonably safe for the gravely wounded, while those desperately injured, even the apparently moribund, are no longer doomed. Mention should also be made of the progress of resuscitation of the severely dehydrated wounded and burned whose need for fluid replacement has sometimes to be reckoned almost in gallons rather than pints.

In anzesthetics as in so many subjects allied to surgery and in war surgery itself, there may have been few real innovations, but war has given an impetus to the much fuller development of existing ideas and has passed on that impetus to civilian surgery. The intravenous administration of barbiturates as the sole or initial method became by far the most frequently employed anæsthetic in the later years. It has been the greatest help to the surgeon, and an inestimable boon to the wounded bringing them immediate tranquillity and relief, instead of a bludgeoning into unconsciousness by the methods of the past. It can be said that the elaboration of this speciality in this war has made possible most of the operative advances, especially those connected with thoracic and thoraco-abdominal wounds, and has removed the "no thoroughfare" noticeboard from the transpleural route.

The treatment of chest wounds has progressed apace. The policy of concentrating on the return of lung function by dealing adequately with the hæmothorax, the prevention or treatment of the complications of hæmothorax and the rehabilitation which accompanies these measures, should pay good dividends in the after-years of these cases. The war has demonstrated the importance of the physician in the chest team, and the value of the chest centre after the patient has had his first few days of preliminary treatment forward.

Abdominal wounds which previously showed a mortality rate at around 70 per cent, now show a recovery rate at that figure. No new surgical measure is responsible but the principle of exteriorizing wounds of the distal half of the colon, and the proven ease of the thoracic approach to the upper abdomen, have been of vast importance. In the post-operative treatment, during the week in which the patient must be held before transfer, many life-saving measures have become routine. Suction decompression must be held to have

- played an important part in the prevention of paralytic ileus, and Fowler's. position appears to have sagged into the horizontal with beneficial rather than untoward results, but the surgeon who uses it correctly and reasonably in frankly infected cases is not necessarily wrong in his beliefs.

War gives a magnificent opportunity for controlled tests, and the best example is that of the evaluation of penicillin., With preliminary adequate surgery 
to eradicate damaged tissues cut of by trauma from the circulation, penicillin has bettered the outlook for wounds in general, has played àn important part in the treatment of joint and chest wounds, and may have done much to prevent the chronic osteomyelitis which used to be such a feature of the years following a war. One lesson that may fairly be claimed to have been learned is that no therapy, using any of the known antibiotic or chemotherapeutic agents, gives any excuse for neglecting the principles of sound war surgery learned in the hard schools of two world wars.

In the treatment of wounds" of the heads at neurosurgical centres there have been notable advances, reducing the mortality rate from nearly 50 to 10 per cent, but space does not permit further details, even to describe the highly satisfactory set-up of the specialized centres-neurosurgical, orthopædic, thoracic, vascular, plastic." Conditions were favourable for the success of these units and they are adaptable to different conditions.

It is a far cry from the covered wagon to air evacuation. Six times the total number of wounded in the South African war went by air to home hospitals from the battlefields of the final campaign in France and Germany. The possibilities of air evacuation-by medical air ambulance convoy-are still immense and range from long-distance evacuation of wounded in large numbers by fast aircraft to picking up wounded survivors from a cut-off armoured or other force, using highly manouvrable planes of the helicopter type.

Since 1945, commitments grow less, but the size of the Army is still too large for the small regular R.A.M.C. to be responsible for its surgical service unaided. For three years the R.A.M.College has concentrated on the training of specialists, those who by reason of the war have been called away to duties unconnected with their speciality, and those who must now or never become more highly qualified. Their successes in obtaining higher diplomas have been a most hopeful augury for the future. The senior and specialist course can now be a year longer than it used to be. Civilian teachers throughout the country give most generous help in special branches of surgery and registrar types of appointment are made available. The wartime consultants, on occasions, lecture at the College. Their friendly help, unstintingly given, as always in the war, is another very happy augury for the difficult future.

With the appointment of colonel consultants in overseas commands, a full Army career in surgery is now possible, and the very legitimate grievance that an Army surgeon, with valuable experience, had to give up the practice of his speciality quite early in his service, has been met.

It is well that at one centre in the kingdom, war surgery should continue to be taught. The lectures at the R.A.M.College are now of 1945 pattern, but that there may be no false sense of security arising from the surgical triumphs of the victorious terminal years of the war, the appalling problems encountered in the earlier years are studied. Atomic warfare, although its lesions do not belong so much to the domain of surgery, now has to be included in the curriculum, for the fifty years of wars draw to a close, still with rumours of war.

Those who have taken part in the military surgical events of this half- 
century, during 'which wellnigh the whole of the history of war surgery has been written; have the great honour to belong to an era which will be unique for all time. Pọsterity may judge them to have been "faithful," it surely must hold that their duties were "arduous."

\section{BIBLIOGRAPHY}

B.L.A. Surgery: Brigadier A. E. Porritt, C.B.E.

Official History of the War. 1914-1918.

Surgical Experiences in South Africa. G. H. Makins, C.B. 